\title{
O SUCESSO DO ANO INTERNACIONAL DA QUÍMICA NO BRASIL
}

O Ano Internacional da Química, AIQ-2011, no Brasil, vai ficar na história. Inúmeras ações e atividades comemorativas foram realizadas em todo o território brasileiro, resultado de uma frutífera parceria entre a Sociedade Brasileira de Química, instituições representativas da Química em todo o Brasil, com destaque para a Associação Brasileira da Indústria Química, ABIQUIM, os Conselhos Regionais de Química, os Museus de Ciência, as Universidades e Escolas de Ensino Fundamental e Médio.

O Ministério de Ciência, Tecnologia e Inovação, MCTI, foi o grande parceiro da SBQ na realização do AIQ. A primeira ação disparada pela SBQ, ainda em 2010, foi abrir um concurso para gerar um selo comemorativo ao AIQ que falasse português. O selo vencedor teve uma extensa repercussão, agregou parceiros e passou a ser usado por Universidades, Escolas, Órgãos Públicos e Indústrias.

O portal do Ano Internacional da Química, www.quimica2011. org.br, coordenado pela SBQ, entrou no ar em janeiro de 2011, com o objetivo de reunir as ações brasileiras neste ano e cumpriu seu papel. De janeiro até outubro, o número de acessos alcançou 200 mil, com destaque para as cidades de São Paulo, Rio de Janeiro e Belo Horizonte.

O portal contemplou várias seções, divulgando eventos que ocorreram no país e disponibilizando livros e exposições sobre a Química no cotidiano, além de entrevistas e moléculas curiosas a cada dia de 2011. A seção AIQ nas Escolas, um canal direto com as escolas de ensino fundamental e médio, mostrou projetos de Química e feiras de ciências que aconteceram por todo o Brasil.

Entre as páginas de maior interesse no portal está o acesso ao livro de experimentos "A Química perto de você - experimentos de baixo custo para o ensino fundamental e médio". Esse livro foi compilado pela SBQ, com a contribuição de diversos grupos brasileiros das áreas de ensino e divulgação de ciências, através de chamadas abertas na rede. Os experimentos foram testados pela Universidade Federal de Santa Maria, e buscaram contribuir para instigar os mais jovens à observação experimental ainda no ensino fundamental. Como todo o material disponibilizado no portal, a exemplo da coleção de livros “A Química no Cotidiano”, possui o ISBN da SBQ e encontra-se livre para ser baixado diretamente do portal.

A segunda seção mais acessada foi a de Eventos. Até o final de outubro encontravam-se cadastrados em torno de 70 eventos relacionados ao AIQ, organizados principalmente por Instituições de Ensino Superior, Museus de Ciências e pelos Conselhos Regionais de Química.

O Brasil teve a oportunidade de receber um número expressivo de cientistas agraciados com o prêmio Nobel, que abrilhantaram as ações comemorativas. O estado de São Paulo acolheu quatro deles de uma só vez, uma ação inédita. Diversas instituições receberam a exposição "A Química no Cotidiano", elaborada pela SBQ em parceria com o Museu da Vida da Fiocruz. No primeiro semestre de 2011, esta exposição, que trouxe à baila temas como energia, agricultura, alimentação, saúde e comunicação, foi apresentada pelos Museus de Ciência em todo país, numa parceria com 20 Secretarias Regionais da SBQ. Em alguns Estados houve uma intensa itinerância da exposição pelo interior, sendo destaque em TVs e jornais locais. A partir de agosto de 2011, a exposição de painéis, acompanhada de um livro de experimentos, foi liberada para acesso livre na rede, tendo sido baixada do portal 960 vezes, de 01 de agosto a 31 de outubro, especialmente por escolas cadastradas de todo país.

A Química também foi cantada e dançada durante o carnaval de 2011, quando Marie Curie e Johanna Dőbehreiner popularam as ruas de Olinda, e enfeitou o carnaval e as jangadas de Maceió. Na Bahia, ela decorou o aeroporto internacional Deputado Luís Eduardo Magalhães. Em Minas Gerais, São Paulo e Santa Catarina, cientistas brasileiras foram homenageadas em alusão às comemorações ao centenário do Nobel de Química de Marie Curie. No Rio de Janeiro, a Química subiu os morros cariocas, onde o prêmio Nobel de 2008, Martin Chalfie, abriu a Semana Nacional de Ciência e Tecnologia medindo o $\mathrm{pH}$ das águas cariocas com alunos do Complexo do Alemão. Em todos os demais Estados brasileiros, houve comemorações criativas, como teatros, oficinas, concursos e exposições.

O portal do AIQ recebeu 40 projetos de escolas de ensino fundamental e médio. Foram atividades muito expressivas, que contaram com a participação direta de estudantes, envolvendo não só a química formal, mas também música, história, vídeos feitos pela garotada e palestras sobre a química no dia a dia. Através da profícua parceria entre a SBQ, a diretoria do Departamento de Popularização e Difusão da Ciência do MCTI/Semana Nacional de Ciência e Tecnologia (SNCT) e os INCTs de Energia e Meio Ambiente e de Materiais Nanoestruturados, o experimento global da água - pH do planeta, tornou-se o maior experimento até hoje já realizado nas escolas brasileiras. Esta ação foi proposta pela Unesco e pela IUPAC e lançada em janeiro de 2011 na abertura do IYC (International Year of Chemistry), em Paris. O objetivo era que jovens de todo o mundo avaliassem e discutissem a qualidade das águas de rios, lagos, nascentes e poços. No Brasil, foram distribuídos, até o final de outubro, cerca de 35.000 kits, através da rede da SNCT com o apoio da SBQ e dos INCTs citados, que iniciaram as ações com a distribuição nos estados da Bahia e de São Paulo, no primeiro semestre de 2011. A medição do pH das águas brasileiras foi a principal ação da SNCT no Brasil, e percorreu inúmeras localidades, desde a aldeia indígena Desana, no Rio Negro, Amazônia, até Santana do Livramento, na fronteira Brasil-Uruguai. No portal da QNINT é possível acompanhar, em tempo real, o cadastro dos experimentos e quem os realizou, desbravando o território brasileiro com esta belíssima ação.

A Química Nova homenageou o AIQ com suas capas e logos nos artigos e este último número é mais uma contribuição da revista a este importante evento, que teve um sucesso estrondoso. Pudemos ver os legisladores, jornalistas e o público em geral se deliciando e descobrindo como a Química é importante no seu codidiano.

Só nos resta agradecer a todos os parceiros desta empreitada, cujos sonhos em torno de uma Química mais consciente, bela e instigante puderam ser concretizados pelo esforço comunitário, num país onde a educação está muito aquém do que seu povo merece.

Claudia Moraes de Rezende Tesoureira da SBQ e Coordenadora do AIQ Vitor F. Ferreira Editor de $Q N$ 